\title{
Arbeidsmarktprognoses Provincie Gelderland naar opleiding en beroep 2017-2022
}

Citation for published version (APA):

Peeters, T., \& Cörvers, F. (2018). Arbeidsmarktprognoses Provincie Gelderland naar opleiding en beroep 2017-2022. ROA. ROA Fact Sheets No. 013 https://doi.org/10.26481/umarof.2018013

Document status and date:

Published: 01/01/2018

DOI:

10.26481/umarof.2018013

Document Version:

Publisher's PDF, also known as Version of record

\section{Please check the document version of this publication:}

- A submitted manuscript is the version of the article upon submission and before peer-review. There can be important differences between the submitted version and the official published version of record.

People interested in the research are advised to contact the author for the final version of the publication, or visit the DOI to the publisher's website.

- The final author version and the galley proof are versions of the publication after peer review.

- The final published version features the final layout of the paper including the volume, issue and page numbers.

Link to publication

\footnotetext{
General rights rights.

- You may freely distribute the URL identifying the publication in the public portal. please follow below link for the End User Agreement:

www.umlib.nl/taverne-license

Take down policy

If you believe that this document breaches copyright please contact us at:

repository@maastrichtuniversity.nl

providing details and we will investigate your claim.
}

Copyright and moral rights for the publications made accessible in the public portal are retained by the authors and/or other copyright owners and it is a condition of accessing publications that users recognise and abide by the legal requirements associated with these

- Users may download and print one copy of any publication from the public portal for the purpose of private study or research.

- You may not further distribute the material or use it for any profit-making activity or commercial gain

If the publication is distributed under the terms of Article $25 \mathrm{fa}$ of the Dutch Copyright Act, indicated by the "Taverne" license above, 
Maastricht University $\&$ ROA

Arbeidsmarktprognoses Provincie Gelderland naar opleiding en beroep 2017-2022

Tim Peeters

Frank Cörvers

Jessie Bakens

Ineke Bijlsma

\section{ROA Fact Sheet}

ROA-F-2018/13

Researchcentrum voor Onderwijs en Arbeidsmarkt | ROA Research Centre For Education and the Labour Market / ROA 


\section{Arbeidsmarktprognoses Provincie Gelderland naar opleiding en beroep 2017-2022}

\section{Inleiding}

De voorliggende factsheet biedt een verdere uitsplitsing van de toekomstige arbeidsmarktperspectieven naar opleiding en beroep voor Gelderland tot 2022. Deze factsheet is een uitbreiding van de meer algemene factsheet voor de Gelderse arbeidsmarkt met nummer ROA-F-20I8/IO. ${ }^{1}$ In deze factsheet wordt in het bijzonder meer aandacht besteed aan een verdere differentiatie van de toekomstige arbeidsmarktperspectieven van schoolverlaters naar richting binnen het middelbaar beroepsonderwijs (mbo), het hoger beroepsonderwijs (hbo) en het wetenschappelijk onderwijs (wo). Daarnaast worden de knelpunten naar beroep voor de Gelderse werkgevers weergegeven. De interpretatie van de perspectieven naar opleiding gebeurt steeds vanuit het perspectief van schoolverlaters en werkzoekenden, terwijl de knelpunten naar beroep vanuit het standpunt van werkgevers worden belicht.

De prognoses bestrijken 83 (excl. overig) opleidingstypes die verdeeld zijn over 24 opleidingscategorieën en zes opleidingsniveaus. ${ }^{2}$ Deze zijn vertaald naar de knelpunten naar beroep in de personeelsvoorziening voor werkgevers. Het betreft gegevens voor II2 beroepsgroepen. Als gevolg van een lage celvulling is deze verdiepingsslag naar opleidingstype en beroepsgroep alleen voor Gelderland als geheel uitgevoerd, en dus niet voor de individuele arbeidsmarktregio's. Rekening houdend met gebiedsspecifieke kenmerken kunnen deze Gelderse prognoses echter op de regio's geprojecteerd worden. Tekstbox I geeft een overzicht van de definities van de in deze factsheet gebruikte kernvariabelen.

De factsheet begint met de belangrijkste bevindingen. Daarna volgt een bespreking van de arbeidsmarktprognoses voor schoolverlaters en werkzoekenden naar opleidingsniveau. Deze prognoses worden vervolgens verder uitgesplitst naar opleidingstype. Tot slot worden de arbeidsmarktknelpunten naar beroep besproken.

I Prognoses voor de onderliggende Gelderse arbeidsmarktregio's zijn te vinden in de factsheets met nummer ROA-F-20I8/IOA voor Stedendriehoek, ROA-F-20I8/IoB voor Midden-Gelderland, ROA-F20I8/IoC voor Food Valley, ROA-F-20I8/IoD voor het Rijk van Nijmegen, ROA-F-2018/IoE voor de Achterhoek, ROA-F-2018/IoF voor Rivierenland en ROA-F-2018/ıoG voor Noordwest Veluwe.

2 Basisonderwijs/vmbo en havo/vwo worden hier nauwelijks besproken omdat deze opleidingsniveaus niet verder worden verbijzonderd naar richting. In de algemene factsheet voor Gelderland (ROA-F20I8/IO) zijn de prognoses voor basisonderwijs/vmbo en havo/vwo weergegeven.

\section{Belangrijkste bevindingen}

- Voor ongeveer een derde van de 83 opleidingstypes wordt in de periode tot 2022 goede of zeer goede arbeidsmarktperspectieven verwacht, terwijl bijna een vijfde van de opleidingstypes matige of slechte vooruitzichten kent. Dit onderstreept het belang van een goede opleidingskeuze door jongeren.

- Op mbo-niveau zijn er voor schoolverlaters en werkzoekenden van mbo $2 / 3$ techniek en mbo 4 techniek de beste toekomstige arbeidsmarktperspectieven. Daarbinnen gelden de gunstigste perspectieven voor technische installatie (mbo $2 / 3$ en mbo 4), werktuigbouwkunde en metaalbewerking (mbo $2 / 3$ en mbo 4 ) en bouw en infra ( $m b o 4)$. Binnen mbo 4 techniek kent media en vormgeving als gevolg van een relatief hoge arbeidsmarktinstroom duidelijk de zwakste vooruitzichten voor schoolverlaters en werkzoekenden. Voor logistieke opleidingen zijn de perspectieven op mbo 4 en hbo-niveau beter dan op mbo 2/3-niveau.

- Schoolverlaters en werkzoekenden van zorgen welzijnsrichtingen kennen uiteenlopende arbeidsmarktperspectieven. Er wordt een relatief grote uitbreidingsvraag voorzien voor zorgberoepen, maar op mbo-niveau leidt dit voor veel opleidingen (en met name voor mbo maatschappelijke zorg) niet tot gunstige arbeidsmarktperspectieven omdat de verwachte arbeidsmarktinstroom van schoolverlaters en werkzoekenden ruimschoots kan voorzien in de vraag. Voor afgestudeerden met een hbo- en wo-opleiding gericht op de zorg zijn de arbeidsmarktperspectieven over het algemeen redelijk of goed. Vanuit werkgeversperspectief is het moeilijk om naast verpleegkundigen op mbo-niveau ook zorgpersoneel op hbo- en wo-niveau te werven.

- De vooruitzichten voor afgestudeerden van een hboen wo-opleiding gericht op het onderwijs zijn in Gelderland respectievelijk goed en redelijk. Desondanks zijn de arbeidsmarktperspectieven van deze groep wat minder gunstig dan voor Nederland als geheel. Voor docenten van beroepsgerichte en algemene vakken in het secundair onderwijs zullen er naar verwachting vrijwel geen knelpunten in de personeelsvoorziening voor werkgevers zijn. Daarentegen worden voor de werving van hoogleraren, docenten hoger onderwijs en vooral leerkrachten basisonderwijs wel grote knelpunten voor werkgevers voorzien.

- Voor een groot deel van de beroepsgroepen binnen de commerciële, agrarische, bedrijfseconomische en administratieve beroepen worden de komende zes jaar (vrijwel) geen knelpunten in de personeelsvoorziening verwacht. Voor de commerciële en de 
bedrijfseconomische en administratieve beroepen kan dat deels verklaard worden door de verwachte impact van automatisering en digitalisering.

- Voor een groot aantal beroepsgroepen in de technische en ICT-beroepen zullen er in de periode tot 2022 grote knelpunten voor werkgevers zijn. Degrootste knelpunten gelden er bij het rekruteren van (elektrotechnisch) ingenieurs, elektriciens, elektronicamonteurs, architecten, technici bouwkunde en natuur en softwareen applicatieontwikkelaars.

\section{Tekstbox 1 Definities kernbegrippen}

\begin{tabular}{|c|c|}
\hline Variabele & Definitie \\
\hline Uitbreidingsvraag & $\begin{array}{l}\text { Vraag naar nieuwe arbeidskrachten die ontstaat door de groei van de werkgelegenheid. Als er sprake is van een werkgelegenheidsdaling, is de uitbreidingsvraag } \\
\text { negatief. }\end{array}$ \\
\hline Vervangingsvraag & $\begin{array}{l}\text { Vervangingsvraag is de vraag naar nieuwe arbeidskrachten die ontstaat door bijvoorbeeld pensionering, (tijdelijke) uittreding vanwege zorgtaken, } \\
\text { arbeidsongeschiktheid, beroepsmobiliteit of doorstroom naar een andere opleiding. }\end{array}$ \\
\hline Arbeidsmarktinstroom & $\begin{array}{l}\text { De arbeidsmarktinstroom is het verwachte aanbod van nieuwe arbeidskrachten op de arbeidsmarkt. Deze is gebaseerd op de verwachte uitstroom van } \\
\text { schoolverlaters uit het initiële dag-, deeltijd-, niet-reguliere voltijdonderwijs en de beroepsgerichte volwasseneneducatie. }\end{array}$ \\
\hline ITA & $\begin{array}{l}\text { Indicator Toekomstige Arbeidsmarktperspectief (ITA) van schoolverlaters en werkzoekenden. Deze indicator is gelijk aan een deling van het verwachte aanbod } \\
\text { door de verwachte vraag tot 2022. Naarmate de waarde van de ITA hoger ligt, is er sprake van een slechter arbeidsmarktperspectief voor schoolverlaters en } \\
\text { werkzoekenden. Een waarde tussen 1,01 en 1,05 duidt op een evenwichtssituatie. }\end{array}$ \\
\hline Typering ITA & $\begin{array}{l}\text { Een kwalitatieve beschrijving van de ITA. ITA } \leq 0,85 \text { wordt als "zeer goed" getypeerd, ITA }>0,85 \text { en } \leq 1,00 \text { als "goed", ITA > 1,00 en } \leq 1,05 \text { als "redelijk", ITA > } \\
1,05 \text { en } \leq 1,15 \text { als "matig" en ITA > 1,15 als"slecht". }\end{array}$ \\
\hline ITKB & $\begin{array}{l}\text { De Indicator Toekomstige Knelpunten in de Personeelsvoorziening naar Beroep (ITKB) geeft aan in welke mate het voor werk } \neg \text { gevers mogelijk is om de } \\
\text { gewenste personeelssamenstelling naar opleidingsachter } \neg \text { grond binnen beroepsgroepen te realiseren, bij de voorspelde vraag-aanbod-verhou } \neg \text { dingen } \\
\text { voor de verschillende opleidingstypen. De ITKB heeft een waarde tussen } 0 \text { en } 1 \text {, waarbij werkgevers bij een waarde van bijvoorbeeld } 0,8 \text { slechts voor } 80 \% \text { de } \\
\text { gewenste samenstelling naar opleiding kunnen realiseren. }\end{array}$ \\
\hline Typering ITKB & $\begin{array}{l}\text { Een kwalitatieve beschrijving van de ITKB die gaat van geen, vrijwel geen, enige, grote tot zeer grote knelpunten in de personeelsvoorziening voor werkgevers. } \\
\text { Om deze typeringen naar beroepsgroep te berekenen worden als tussenstap eerst de knelpunten naar opleidingstype berekend. Hieraan worden dan typeringen } \\
\text { toegekend die dezelfde grenzen hebben als de ITA-typeringen. De verdeling van deze typeringen naar opleidingstype wordt vervolgens overgenomen om de } \\
\text { typeringen voor de ITKB's te bepalen. Wanneer er dus bijvoorbeeld voor 10\% van de opleidingstypes zeer grote knelpunten worden voorzien, wordt opgelegd } \\
\text { dat dit 0ok voor 10\% van de beroepsgroepen wordt verwacht. Dit heeft tot gevolg dat de ITKB-grenswaardes bij deze typeringen moeilijk kunnen vergeleken } \\
\text { worden tussen bijvoorbeeld Gelderland en Nederland. }\end{array}$ \\
\hline Werkloosheid & abben gezocht en daarvoor direct beschikbaar zijn als percentage van de beroepsbevolking. \\
\hline
\end{tabular}




\section{Prognoses naar opleidingsniveau}

Tabel I geeft een samenvattend beeld van de arbeidsmarktperspectieven naar opleidingsniveau voor Gelderland, Nederland, en de zes Gelderse arbeidsmarktregio's: Stedendriehoek en Noordwest Veluwe (gesplitst in de twee deelregio's), Midden-Gelderland, Food Valley, het Rijk van Nijmegen, de Achterhoek en Rivierenland. Deze arbeidsmarktperspectieven worden voorgesteld door de zogenoemde Indicator Toekomstig Arbeidsmarktperspectief (ITA) voor schoolverlaters en werkzoekenden, in de vorm van een kwalitatieve typering van de ITA.

Zoals eveneens vermeld in Tekstbox I, toont de ITA voor elk opleidingstype de verwachte verhouding tussen het totale arbeidsaanbod (instroom en werkloosheid) en de totale arbeidsvraag (vervangingsvraag, substitutievraag en positieve uitbreidingsvraag) over de prognoseperiode 20172022. Wanneer de ITA tussen I,OI en I,Os ligt, zijn vraag en aanbod min of meer in evenwicht en wordt gesproken van een "redelijk" arbeidsmarktperspectief. Een opleidingstype met een ITA groter dan I,O5 krijgt als kwalitatieve typering "matig", en zelfs "slecht" wanneer de waarde groter is dan I,I5. Wanneer het aanbod daarentegen kleiner is dan de vraag en de ITA daardoor kleiner is dan I,Oo wordt het arbeidsmarktperspectief als "goed" aangeduid. De typering "zeer goed" geldt bij een ITA kleiner dan of gelijk aan $0,85 .{ }^{3}$

Op geaggregeerd niveau wordt voor Gelderland de komende zes jaar min of meer een arbeidsmarktevenwicht verwacht. Dit is voor schoolverlaters en werkzoekenden over het algemeen iets minder gunstig dan de vooruitzichten voor Nederland als geheel. Dat komt met name omdat de verwachtingen voor middelbaar opgeleide schoolverlaters van $\mathrm{mbo} / 3$ en mbo 4 minder gunstig zijn in Gelderland. Hoogopgeleiden hebben in Gelderland gunstigere arbeidsmarktperspectieven dan middelbaar geschoolden. Dit beeld geldt ook voor Nederland als geheel.

Schoolverlaters en werkzoekenden van het basisonderwijs en vmbo zullen in de periode tot 2022 weinig moeite hebben om een baan te vinden, zowel binnen Gelderland als in Nederland. Een aanzienlijk deel van de vraag naar personen met basisonderwijs of vmbo als opleidingsachtergrond heeft echter betrekking op laagbetaalde en kleine banen. Bovendien gaat het vaak om flexibele banen met weinig doorgroeimogelijkheden en een beperkte loongroei gedurende de loopbaan. Verder is van belang dat de groep van laagopgeleiden met basisonderwijs

3 De ITA-typeringen zijn gebaseerd op een statistische analyse van de spreiding van de arbeidsmarktsituatie van de verschillende opleidingstypen. Zie M. Wieling, A. de Grip en E. Willems (1990), Een systematische kwalitatieve typering van arbeidsmarktinformatie, ROA-W-I990/8, Maastricht: ROA. of vmbo heel heterogeen is: niet alleen scholieren, maar ook voortijdig schoolverlaters zonder startkwalificatie (minimaal mbo 2 of havo), schoolverlaters van het speciaal onderwijs en arbeidsgehandicapten maken er deel van uit. Bij het aangegeven goede arbeidsmarktperspectief is bovendien geen rekening gehouden met de mogelijke sociale, fysieke en cognitieve beperkingen van een groot deel van de mensen binnen deze groep.

Daarnaast valt het op dat de arbeidsmarktperspectieven van schoolverlaters en werkzoekenden in de zeven arbeidsmarktregio's vrij dicht bij elkaar liggen. De minst gunstige vooruitzichten gelden er voor het Rijk van Nijmegen, hoewel dit nog steeds neerkomt op een redelijk arbeidsmarktperspectief.Debestearbeidsmarktperspectieven worden verwacht voor Rivierenland vanwege een licht vraagoverschot. Verder valt op dat er voor zowel mbo $2 / 3$ als mbo 4 in alle arbeidsmarktregio's een aanbodoverschot wordt voorzien, en dat hoger opgeleiden duidelijk zwakkere vooruitzichten kennen in het Rijk van Nijmegen. Dit kan verklaard worden door het relatief grote aanbod van hoger opgeleide schoolverlaters van de universiteit en het hoger beroepsonderwijs in het Rijk van Nijmegen.

\section{Toekomstige arbeidsmarktperspectieven voor mbo-} schoolverlaters

Figuur I geeft de arbeidsmarktprognoses tot 2022 weer voor schoolverlaters en werkzoekenden met een mbo 2/3- of mbo 4-opleiding. Dit wordt voorgesteld door per mbo-opleidingstype de verwachte totale vraag en het verwachte totale aanbod tegen elkaar af te zetten. De kleuren bakenen de gebieden af die corresponderen met de vijf eerder besproken ITA-typeringen voor schoolverlaters, gaande van slecht $($ ITA $>$ I,I5) tot zeer goed (ITA $\leq 0,85)$. Voor de punten op de middelste diagonale lijn zijn verwachte vraag en aanbod aan elkaar gelijk, wat correspondeert met een ITA gelijk aan I,Oo. Bijvoorbeeld, voor mbo $2 / 3$ technische installatie bedragen het totale aanbod en de totale vraag over zes jaar respectievelijk (afgerond) 26\% en 33\%. Deze waarden impliceren een ITA van 0,95 , zodat mbo $2 / 3$ technische installatie zich bevindt in het gebied met typering "goed" ${ }^{4}$ Merk op dat deze ITA een gemiddelde betreft van het opleidingstype mbo $2 / 3$ technische installatie, en dat er variatie kan bestaan in de arbeidsmarktperspectieven (ITA's) van de onderliggende opleidingen.

Merk op dat de typeringen van de arbeidsmarktperspectieven zijn opgesteld vanuit het standpunt van schoolverlaters en werkzoekenden. Voor

4 De berekening van de ITA is niet louter een deling van aanbod en vraag, aangezien teller en noemer nog dienen vermeerderd te worden met Ioo. 
werkgevers geldt echter de omgekeerde interpretatie. Over het algemeen betekent een goed (slecht) arbeidsmarktperspectief voor werkzoekenden van een bepaald opleidingstype dat werkgevers veel (weinig) moeite moeten doen om werknemers aan te trekken met deze opleidingsachtergrond.

Ter aanvulling van Figuur I worden in Tabel 2 de belangrijkste vraag- en aanbodcomponenten van de ITA weergegeven voor de opleidingstypes binnen het middelbaar (beroeps)onderwijs. Telkens worden daarbij de jaarlijkse uitbreidingsvraag (UV), vervangingsvraag (VV) en arbeidsmarktinstroom getoond als percentage van de werkzame beroepsbevolking in 20I6. De uitbreidingsvraag, vervangingsvraag en instroom vormen samen met de werkloosheid en de substitutievraag (niet weergegeven) de componenten van de kwalitatieve beschrijving van het perspectief voor schoolverlaters en werkzoekenden in de laatste kolom. Daarnaast zijn ook de prognoses voor de bovenliggende opleidingscategorieën opgenomen zodat nagegaan kan worden in hoeverre de voorspellingen voor de opleidingstypes hiervan afwijken.

Uit Figuur I blijkt dat schoolverlaters en werkzoekenden van technische studies op mbo-niveau de beste

5 De ITA's naar opleidingstype voor Nederland als geheel zijn te vinden in het bijgeleverde Excel-bestand. arbeidsmarktperspectieven hebben, terwijl de perspectieven voor mbo groen en enkele economie-opleidingen het minst gunstig zijn. De goede vooruitzichten voor mbo'ers met een technische opleiding gelden vooral voor de schoolverlaters en werkzoekenden met een diploma werktuigbouwkunde en metaalbewerking ( $m b o \quad 4)$, technische installatie ( $m$ bo $2 / 3$ en mbo 4 ), en bouw en infra (mbo 4). De arbeidsmarktperspectieven voor dit opleidingstype zijn goed, en beter dan het gemiddelde voor mbo techniek als geheel. Op mbo 4-niveau komt dit vooral door een relatief hoge vervangingsvraag naar mensen met deze opleiding, en een relatief lage instroom van schoolverlaters met deze opleiding. Binnen de zorg- en welzijnsopleidingen zijn de perspectieven voor gezondheidszorg ( $m b o r / 3$ en mbo 4) en schoonheids- en haarverzorging (mbo 4 ) beter dan de overige opleidingstypes binnen deze richting. Voor de andere zorg- en welzijnsopleidingen wordt er een relatief grote arbeidsmarktinstroom van schoolverlaters voorzien, waardoor er ondanks de relatief hoge uitbreidingsvraag naar verwachting genoeg personeel beschikbaar zal zijn om aan de vraag van werkgevers te voldoen. Ditzelfde geldt ook voor de economische opleidingen op mbo 2/3- en mbo 4-niveau. Daar zijn de arbeidsmarktperspectieven over het algemeen matig, behalve voor facilitaire dienstverlening ( $\mathrm{mbo} 2 / 3$ ) als gevolg van een relatief grote verwachte vervangingsvraag.

Tabel 1

Toekomstig arbeidsmarktperspectief voor schoolverlaters en werkzoekenden 2017-2022 naar regio en opleidingsniveau

\begin{tabular}{|c|c|c|c|c|c|c|c|}
\hline & bo/vmbo & havo/vwo & mbo $2 / 3$ & mbo 4 & hbo & wo & totaal \\
\hline \multicolumn{8}{|l|}{ ITA } \\
\hline Gelderland & 0,93 & 1,04 & 1,07 & 1,08 & 1,04 & 0,99 & 1,01 \\
\hline Nederland & 0,90 & 1,03 & 1,05 & 1,04 & 1,01 & 0,98 & 0,99 \\
\hline Stedendriehoek & 0,92 & 0,99 & 1,08 & 1,07 & 1,00 & 0,95 & 1,00 \\
\hline Noordwest Veluwe & 0,92 & 1,03 & 1,14 & 1,11 & 1,03 & 0,81 & 1,01 \\
\hline Midden-Gelderland & 0,93 & 0,99 & 1,02 & 1,07 & 1,03 & 0,95 & 1,00 \\
\hline Food Valley & 0,92 & 1,07 & 1,08 & 1,07 & 1,01 & 0,99 & 1,01 \\
\hline Rijk van Nijmegen & 0,87 & 1,12 & 1,03 & 1,06 & 1,11 & 1,11 & 1,04 \\
\hline Achterhoek & 0,94 & 1,02 & 1,07 & 1,08 & 1,05 & 0,87 & 1,02 \\
\hline Rivierenland & 0,93 & 0,97 & 1,08 & 1,07 & 0,99 & 0,90 & 0,99 \\
\hline \multicolumn{8}{|l|}{ Typering ITA } \\
\hline Gelderland & goed & redelijk & matig & matig & redelijk & goed & redelijk \\
\hline Nederland & goed & redelijk & redelijk & redelijk & redelijk & goed & goed \\
\hline Stedendriehoek & goed & goed & matig & matig & goed & goed & goed \\
\hline Noordwest Veluwe & goed & redelijk & matig & matig & redelijk & zeer goed & redelijk \\
\hline Midden-Gelderland & goed & goed & redelijk & matig & redelijk & goed & goed \\
\hline Food Valley & goed & matig & matig & matig & redelijk & goed & redelijk \\
\hline Rijk van Nijmegen & goed & matig & redelijk & matig & matig & matig & redelijk \\
\hline Achterhoek & goed & redelijk & matig & matig & redelijk & goed & redelijk \\
\hline Rivierenland & goed & goed & matig & matig & goed & goed & goed \\
\hline
\end{tabular}




\section{Figuur 1}

Vraag en aanbod naar opleidingstype voor Gelderland, mbo 2/3 en mbo 4, 2017-2022*

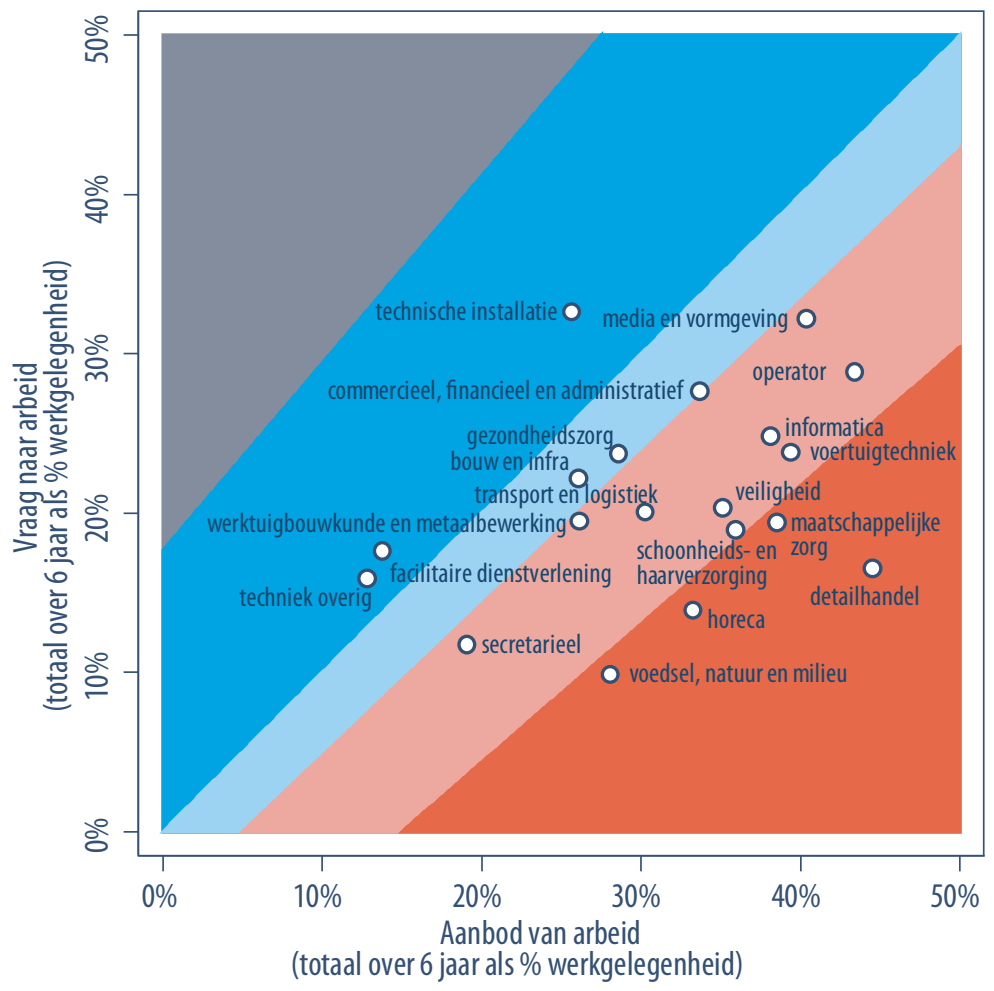

\begin{tabular}{|c|c|}
\hline & Perspectief zeer goed \\
& Perspectief goed \\
& Perspectief redelijk \\
& Perspectief matig \\
& Perspectief slecht \\
& mbo $2 / 3$ \\
\hline 0 & \\
\hline
\end{tabular}

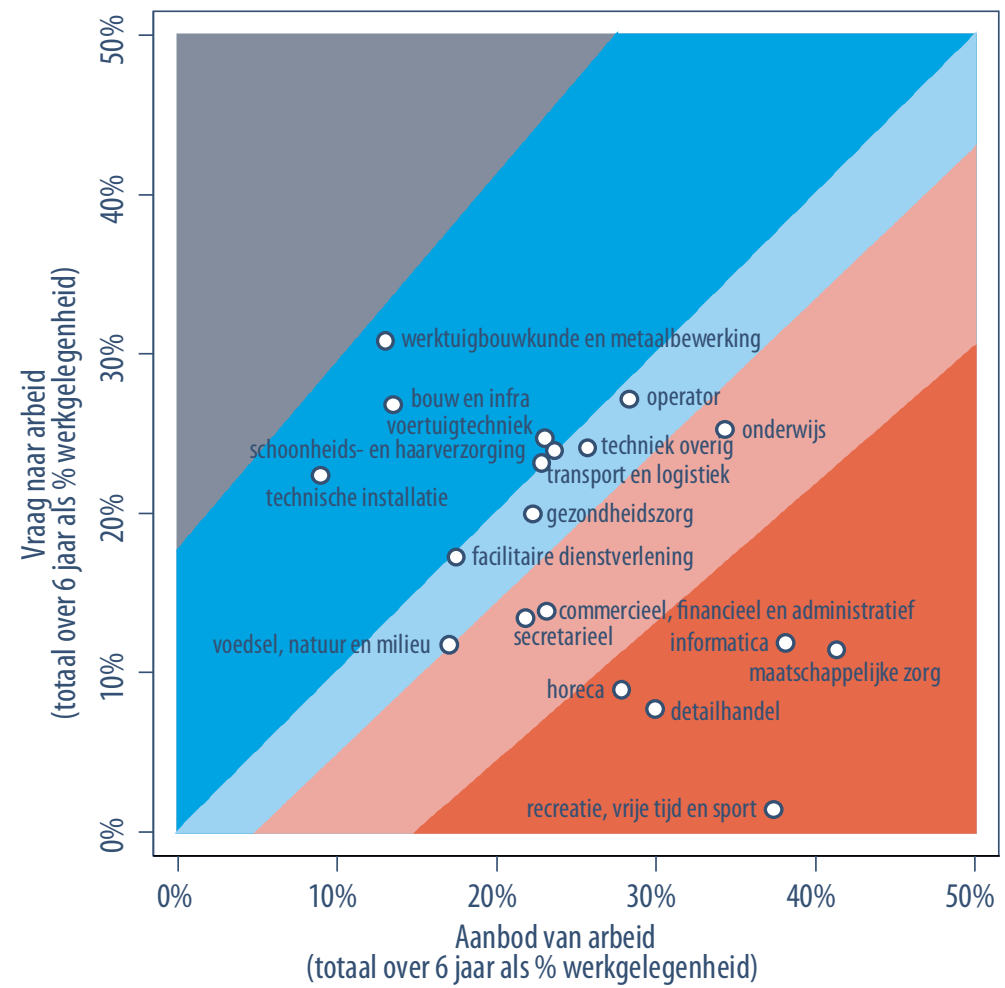

\begin{tabular}{|c|l|}
\hline & Perspectief zeer goed \\
\hline & Perspectief goed \\
& Perspectief redelijk \\
& Perspectief matig \\
\hline & Perspectief slecht \\
& mb0 4 \\
\hline 0 & \\
\hline
\end{tabular}

* Om de leesbaarheid van de figuur te vergroten zijn twee opleidingstypes met een slecht arbeidsmarktperspectief (erg groot aanbod en een lage vraag) weggelaten: $\mathrm{mbo} 2 / 3$ recreatie, vrije tijd en sport en mbo 4 media en vormgeving. Zie Tabel 2 voor de prognoses van deze opleidingstypes. 
De toekomstige arbeidsmarktperspectieven voor schoolverlaters en werkzoekenden van mbo $2 / 3$ in Gelderland zijn vergelijkbaar met, of net iets minder gunstig dan voor Nederland (zie ook het bijgeleverde Excelbestand). Dat komt vooral doordat de economische groei en de banengroei in Gelderland iets lager ligt dan gemiddeld in Nederland. De vooruitzichten van schoolverlaters van de opleidingstypes mbo $2 / 3$ secretarieel, mbo $2 / 3$ informatica, mbo $2 / 3$ media en vormgeving, mbo $2 / 3$ werktuigbouwkunde en metaalbewerking, mbo $2 / 3$ bouw en infra, mbo $2 / 3$ transport en logistiek, en mbo $2 / 3$ voedsel, natuur en milieu zijn net iets slechter dan gemiddeld in Nederland. Alleen de perspectieven voor schoolverlaters van mbo 2/3 schoonheids- en haarverzorging zijn in Gelderland iets gunstiger dan in de rest van Nederland.

Ook voor mbo 4 zijn de toekomstige arbeidsmarktperspectieven voor schoolverlaters en werkzoekenden van sommige opleidingstypes iets afwijkend van de perspectieven voor Nederland. Binnen de technische opleidingen zijn er goede arbeidsmarktperspectieven voor schoolverlaters of werkzoekenden met een diploma mbo 4 werktuigbouwkunde en metaalbewerking, mbo 4 technische installatie, en mbo 4 operator, ofschoon net iets minder gunstig dan in Nederland als geheel. De vooruitzichten voor schoolverlaters en werkzoekenden van mbo 4 techniek overig en mbo 4 transport en logistiek zijn in Gelderland daarentegen beduidend beter dan gemiddeld in Nederland. De perspectieven voor schoolverlaters met mbo 4 detailhandel zijn in Gelderland slecht, en ook minder gunstig dan in de rest van Nederland. Binnen mbo 4 zorg en welzijn zijn de perspectieven over alle opleidingstypes heen gemiddeld slechts matig als gevolg van een relatief hoge arbeidsmarktinstroom. Daarbinnen hebben schoolverlaters met een opleiding gericht op het onderwijs iets minder gunstige arbeidsmarktvooruitzichten dan in Nederland, vanwege een lagere vervangingsvraag door bijvoorbeeld veel jong personeel als onderwijsassistent of als medewerker in de kinderopvang. Hetzelfde geldt voor schoolverlaters van een opleiding gericht op de gezondheidszorg vanwege een lagere uitbreidingsvraag in Gelderland dan in Nederland.

\section{Toekomstige arbeidsmarktperspectieven voor hbo- en} wo-schoolverlaters

Figuur 2 laat zien dat ook in het hoger onderwijs de vooruitzichten voor schoolverlaters en werkzoekenden van techniekopleidingen het meest gunstig zijn. Hierbij zijn de arbeidsmarktperspectieven voor werktuigbouwkunde (hbo en wo), chemie (hbo), bouwkunde en civiele techniek (hbo), en informatica (wo) zelfs zeer goed. Ook de vooruitzichten voor hbo elektrotechniek, hbo transport en logistiek, hbo fysiotherapie, hbo natuur en milieu, hbo leraar basisonderwijs, en hbo kunst zijn goed. Binnen het wo zijn de perspectieven ook goed voor wo economie, wo recht, wo politicologie en sociologie, wo geneeskunde en tandheelkunde, wo natuur- en scheikunde, en wo communicatie. Uit Tabel 3 blijkt dat voor deze opleidingstypen de verwachte vervangingsvraag redelijk hoog is, en de verwachte arbeidsmarktinstroom relatief laag. Voor bouwkunde (en civiele techniek) is ook de verwachte uitbreidingsvraag relatief hoog. Hbo economie, in het bijzonder recht, en hotel, vrije tijd en facility management, en hbo communicatie en journalistiek scoren slecht als gevolg van een vrij grote verwachte instroom vanuit het onderwijs op de arbeidsmarkt. Binnen het wo is kunst het enige opleidingstype met slechte vooruitzichten, eveneens als gevolg van een relatief grote arbeidsmarktinstroom van schoolverlaters met deze opleidingsachtergrond. Dit in tegenstelling tot de opleidingen binnen hbo kunst, waarvan de curricula zich de laatste jaren veel meer ontwikkeld hebben tot vraaggerichte opleidingen. Net als in de rest van Nederland zijn ook in Gelderland de arbeidsmarktperspectieven voor hoger opgeleiden over het algemeen beter dan voor middelbaar opgeleiden.

In vergelijking met Nederland zijn de perspectieven voor schoolverlaters en werkzoekenden van hbo leraar beroepsgerichte vakken en leraar algemene vakken minder gunstig in Gelderland. Hetzelfde geldt voor schoolverlaters van hbo pedagogiek, maatschappelijk werk, verpleegkunde en medische diagnostiek, en journalistiek. De vooruitzichten voor schoolverlaters van hbo natuur en milieu zijn in Gelderland goed, terwijl deze in Nederland gemiddeld slechts redelijk zijn. Verder zijn de vooruitzichten voor schoolverlaters van hbo informatica in Nederland gemiddeld genomen goed, terwijl deze in Gelderland redelijk zijn.

Opwo-niveau (zie Tabel 4) zijn de arbeidsmarktperspectieven voor Gelderse schoolverlaters van de opleidingstypes gezondheidszorg, werktuigbouwkunde en elektrotechniek, accountancy en financiën, bedrijfseconomie en logistiek, en communicatie achtergrond beter dan in Nederland. De vooruitzichten voor schoolverlaters van de opleidingstypes onderwijs, psychologie en maatschappelijk werk, en biologie, wiskunde, landbouw en milieu zijn daarentegen juist wat minder gunstig dan in Nederland. 
Tabel 2

Arbeidsmarktprognoses naar opleidingstype voor Gelderland, middelbare opleidingstypes 2017-2022*

\begin{tabular}{|c|c|c|c|c|c|}
\hline Opleidingstypes binnen opleidingscategorie & UV (\%) & VV (\%) & Instroom (\%) & ITA & $\begin{array}{l}\text { Perspectief } \\
\text { schoolverlaters }\end{array}$ \\
\hline mbo $2 / 3$ economie & 0,6 & 2,6 & 4,3 & 1,14 & matig \\
\hline commercieel, financieel en administratief & 1,1 & 3,5 & 4,3 & 1,05 & redelijk \\
\hline Detailhandel & 0,7 & 2,3 & 5,6 & 1,24 & slecht \\
\hline Secretarieel & 0,2 & 2,1 & 2,5 & 1,07 & matig \\
\hline Informatica & 0,2 & 3,5 & 4,7 & 1,11 & matig \\
\hline Horeca & 0,6 & 1,6 & 3,9 & 1,18 & slecht \\
\hline recreatie, vrijetijd en sport & 0,6 & 2,7 & 9,7 & 1,57 & slecht \\
\hline facilitaire dienstverlening & 0,6 & 2,5 & 2,1 & 0,97 & goed \\
\hline Veiligheid & 0,4 & 2,7 & 5,0 & 1,13 & matig \\
\hline mbo $2 / 3$ groen & 0,1 & 1,4 & 4,3 & 1,17 & slecht \\
\hline voedsel, natuur en milieu & 0,1 & 1,4 & 4,3 & 1,17 & slecht \\
\hline mbo $2 / 3$ techniek & 0,8 & 2,6 & 3,8 & 1,04 & redelijk \\
\hline media en vormgeving & 1,3 & 3,7 & 4,6 & 1,07 & matig \\
\hline werktuigbouwkunde en metaalbewerking & 0,8 & 2,0 & 3,7 & 1,06 & matig \\
\hline technische installatie & 1,0 & 3,7 & 3,6 & 0,95 & goed \\
\hline Operator & 0,8 & 3,6 & 5,8 & 1,12 & matig \\
\hline Voertuigtechniek & 1,1 & 2,5 & 5,3 & 1,13 & matig \\
\hline techniek overig & 0,8 & 1,8 & 1,6 & 0,98 & goed \\
\hline bouw en infra & 0,7 & 2,2 & 3,6 & 1,04 & redelijk \\
\hline transport en logistiek & 0,5 & 2,5 & 4,2 & 1,09 & matig \\
\hline mbo $2 / 3$ zorg en welzijn & 1,5 & 2,1 & 4,3 & 1,08 & matig \\
\hline gezondheidszorg & 1,8 & 2,0 & 3,8 & 1,04 & redelijk \\
\hline maatschappelijke zorg & 0,8 & 2,5 & 5,3 & 1,17 & slecht \\
\hline schoonheids- en haarverzorging & 0,8 & 2,0 & 4,9 & 1,15 & matig \\
\hline mbo 4 economie & 0,3 & 1,8 & 3,5 & 1,14 & matig \\
\hline commercieel, financieel en administratief & 0,8 & 1,8 & 3,2 & 1,09 & matig \\
\hline Detailhandel & 0,0 & 1,7 & 4,2 & 1,21 & slecht \\
\hline Secretarieel & 0,1 & 2,5 & 2,7 & 1,08 & matig \\
\hline Informatica & 0,5 & 1,1 & 5,1 & 1,24 & slecht \\
\hline Horeca & 0,2 & 1,4 & 4,0 & 1,18 & slecht \\
\hline recreatie, vrijetijd en sport & 0,0 & 0,7 & 5,3 & 1,36 & slecht \\
\hline facilitaire dienstverlening & 0,5 & 2,7 & 2,4 & 1,01 & redelijk \\
\hline mbo 4 groen & 0,1 & 1,8 & 2,7 & 1,06 & matig \\
\hline voedsel, natuur en milieu & 0,1 & 1,8 & 2,7 & 1,06 & matig \\
\hline mbo 4 techniek & 0,8 & 2,9 & 3,0 & 0,99 & goed \\
\hline media en vormgeving & 1,0 & 2,3 & 9,3 & 1,49 & slecht \\
\hline werktuigbouwkunde en metaalbewerking & 1,0 & 3,3 & 1,8 & 0,87 & goed \\
\hline technische installatie & 0,7 & 2,5 & 1,1 & 0,90 & goed \\
\hline Operator & 0,6 & 3,4 & 3,5 & 1,01 & redelijk \\
\hline Voertuigtechniek & 0,8 & 3,0 & 3,0 & 0,99 & goed \\
\hline techniek overig & 0,7 & 3,1 & 3,1 & 1,02 & redelijk \\
\hline bouw en infra & 0,7 & 2,9 & 1,6 & 0,90 & goed \\
\hline transport en logistiek & 0,9 & 2,6 & 3,0 & 1,00 & goed \\
\hline mbo 4 zorg en welzijn & 1,8 & 1,2 & 4,4 & 1,11 & matig \\
\hline Onderwijs & 1,5 & 2,5 & 4,8 & 1,08 & matig \\
\hline gezondheidszorg & 2,3 & 0,9 & 3,3 & 1,02 & redelijk \\
\hline maatschappelijke zorg & 0,8 & 1,1 & 5,8 & 1,27 & slecht \\
\hline schoonheids- en haarverzorging & 1,1 & 2,7 & 3,5 & 1,00 & goed \\
\hline
\end{tabular}

* Prognoses als gemiddeld jaarlijks percentage van de werkzame beroepsbevolking in 2016 
Figuur 2

Vraag en aanbod naar opleidingstype voor Gelderland, hbo en wo (2017-2022)*

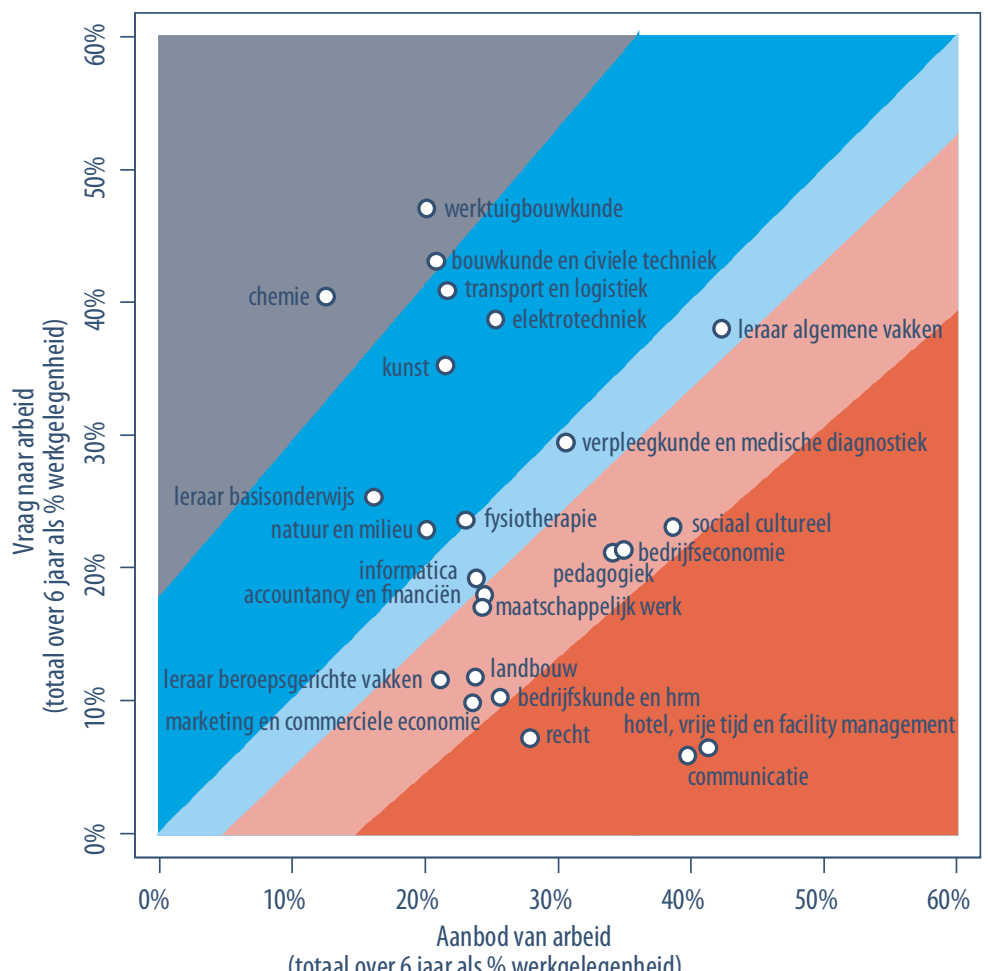

\begin{tabular}{|c|c|}
\hline & Perspectief zeer goed \\
\hline & Perspectief goed \\
& Perspectief redelijk \\
& Perspectief matig \\
& Perspectief slecht \\
& hbo \\
\hline$\circ$ & \\
\hline
\end{tabular}

(totaal over 6 jaar als \% werkgelegenheid)

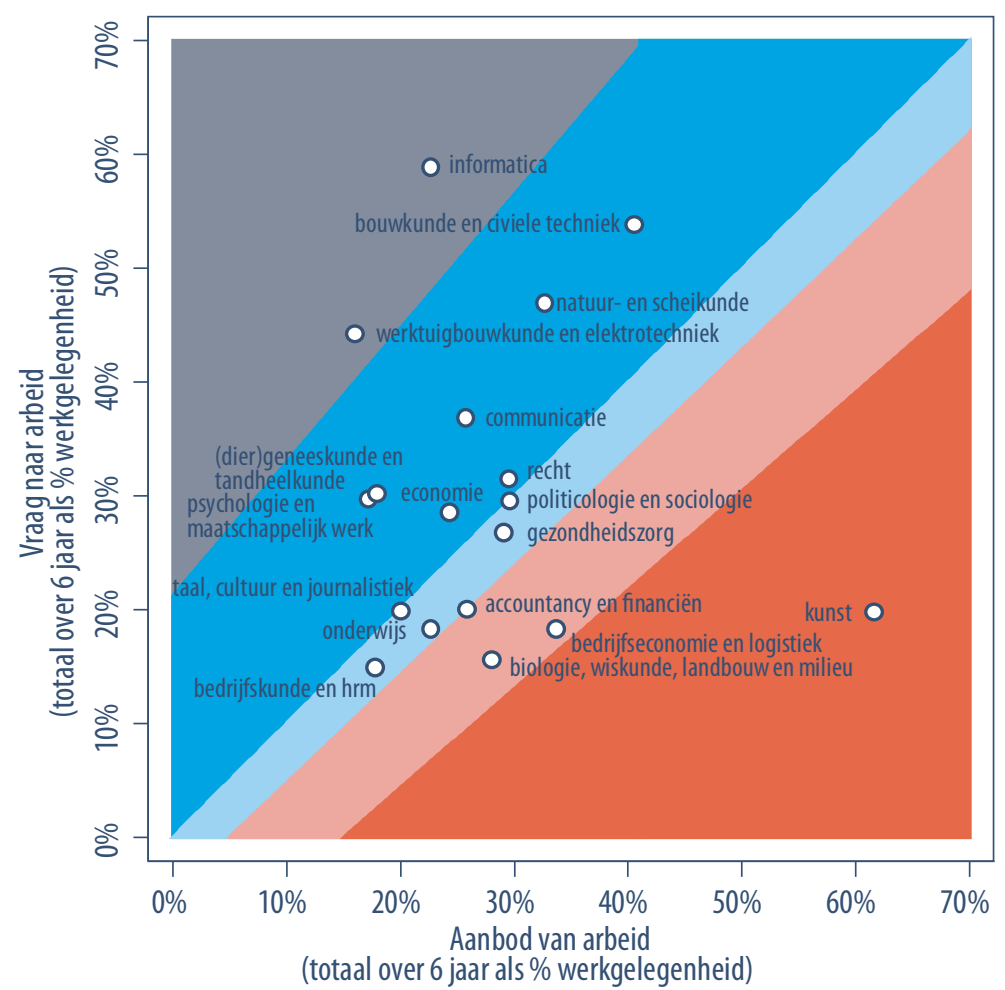

\begin{tabular}{|c|l|}
\hline & Perspectief zeer goed \\
\hline & Perspectief goed \\
& Perspectief redelijk \\
\hline & Perspectief matig \\
\hline & Perspectief slecht \\
\hline $0 \quad$ wo \\
\hline
\end{tabular}

* Om de leesbaarheid van de figuur te vergroten is hbo journalistiek vanwege een erg groot aanbod en een lage vraag (slecht arbeidsmarktperspectief) weggelaten. Zie Tabel 3 voor de prognoses van dit opleidingstype. 
Tabel 3

Arbeidsmarktprognoses naar opleidingstype voor Gelderland, hbo-opleidingstypes 2017-2022

\begin{tabular}{|c|c|c|c|c|c|}
\hline Opleidingstypes binnen opleidingscategorie & UV (\%) & VV (\%) & Instroom (\%) & ITA & $\begin{array}{l}\text { Perspectief } \\
\text { schoolverlaters }\end{array}$ \\
\hline hbo economie & 0,4 & 1,6 & 4,1 & 1,16 & slecht \\
\hline bedrijfseconomie & 1,5 & 1,9 & 5,1 & 1,12 & matig \\
\hline marketing en commerciële economie & 0,3 & 1,4 & 3,8 & 1,15 & matig \\
\hline accountancy en financiën & 0,7 & 2,1 & 3,6 & 1,06 & matig \\
\hline bedrijfskunde en hrm & 0,1 & 1,7 & 3,4 & 1,13 & matig \\
\hline recht & 0,2 & 1,1 & 4,1 & 1,20 & slecht \\
\hline hotel, vrijetijd en facility management & 0,1 & 1,2 & 5,8 & 1,33 & slecht \\
\hline hbo landbouw en natuur & 0,5 & 2,9 & 3,3 & 1,06 & matig \\
\hline natuur en milieu & 0,6 & 2,9 & 2,1 & 0,98 & goed \\
\hline landbouw & 0,2 & 1,7 & 3,0 & 1,11 & matig \\
\hline hbo techniek & 0,9 & 4,5 & 2,7 & 0,89 & goed \\
\hline informatica & 0,6 & 2,2 & 2,9 & 1,04 & redelijk \\
\hline werktuigbouwkunde & 0,9 & 5,6 & 2,5 & 0,82 & zeer goed \\
\hline elektrotechniek & 0,4 & 4,9 & 3,4 & 0,91 & goed \\
\hline chemie & 0,7 & 4,9 & 1,2 & 0,81 & zeer goed \\
\hline bouwkunde en civiele techniek & 1,3 & 4,8 & 2,4 & 0,85 & zeer goed \\
\hline transport en logistiek & 1,8 & 4,3 & 2,4 & 0,87 & goed \\
\hline hbo taal en cultuur & 0,8 & 3,7 & 5,0 & 1,07 & matig \\
\hline kunst & 0,7 & 4,5 & 2,7 & 0,90 & goed \\
\hline communicatie & 0,6 & 0,3 & 5,2 & 1,33 & slecht \\
\hline journalistiek & 0,9 & 4,1 & 9,9 & 1,33 & slecht \\
\hline hbo gedrag en maatschappij & 0,4 & 2,7 & 4,3 & 1,10 & matig \\
\hline pedagogiek & 0,6 & 2,6 & 5,0 & 1,11 & matig \\
\hline sociaal cultureel & 0,0 & 3,5 & 5,4 & 1,13 & matig \\
\hline maatschappelijk werk & 0,6 & 2,2 & 3,5 & 1,07 & matig \\
\hline hbo onderwijs & $-0,1$ & 3,7 & 2,8 & 0,97 & goed \\
\hline leraar basisonderwijs & $-0,2$ & 3,8 & 2,3 & 0,93 & goed \\
\hline leraar algemene vakken & 2,2 & 3,6 & 6,0 & 1,04 & redelijk \\
\hline leraar beroepsgerichte vakken & $-0,6$ & 1,7 & 2,9 & 1,09 & matig \\
\hline hbo gezondheidszorg & 2,0 & 2,5 & 4,3 & 1,02 & redelijk \\
\hline verpleegkunde en medische diagnostiek & 2,3 & 2,4 & 4,4 & 1,01 & redelijk \\
\hline fysiotherapie & 1,2 & 2,5 & 3,5 & 1,00 & goed \\
\hline
\end{tabular}

* Prognoses als gemiddeld jaarlijks percentage van de werkzame beroepsbevolking in 2016 
Tabel 4

Arbeidsmarktprognoses naar opleidingstype voor Gelderland, wo-opleidingstypes 2017-2022*

\begin{tabular}{|c|c|c|c|c|c|}
\hline Opleidingstypes binnen opleidingscategorie & UV (\%) & VV (\%) & Instroom (\%) & ITA & $\begin{array}{l}\text { Perspectief } \\
\text { schoolverlaters }\end{array}$ \\
\hline wo economie en recht & 0,8 & 2,4 & 2,8 & 1,02 & redelijk \\
\hline economie & 0,9 & 3,7 & 2,1 & 0,91 & goed \\
\hline bedrijfseconomie en logistiek & 1,0 & 1,8 & 4,4 & 1,13 & matig \\
\hline accountancy en financiën & 0,8 & 2,3 & 3,6 & 1,05 & redelijk \\
\hline bedrijfskunde en hrm & 0,8 & 1,6 & 2,1 & 1,03 & redelijk \\
\hline recht & 0,9 & 3,8 & 3,8 & 0,99 & goed \\
\hline wo landbouw en natuur & 0,7 & 2,3 & 3,9 & 1,08 & matig \\
\hline biologie, wiskunde, landbouw en milieu & 0,4 & 1,8 & 3,8 & 1,11 & matig \\
\hline natuur-en scheikunde & 1,9 & 4,7 & 4,1 & 0,91 & goed \\
\hline wo techniek & 1,1 & 5,6 & 3,1 & 0,85 & zeer goed \\
\hline informatica & 1,5 & 6,7 & 3,1 & 0,78 & zeer goed \\
\hline werktuigbouwkunde en elektrotechniek & 0,8 & 5,3 & 2,1 & 0,81 & zeer goed \\
\hline bouwkunde en civiele techniek & 1,6 & 6,0 & 5,6 & 0,92 & goed \\
\hline wo taal en cultuur & 0,7 & 2,9 & 4,1 & 1,07 & matig \\
\hline kunst & 0,3 & 2,8 & 7,9 & 1,35 & slecht \\
\hline taal, cultuur en journalistiek & 0,8 & 2,2 & 2,6 & 1,01 & redelijk \\
\hline communicatie & 0,6 & 4,9 & 3,7 & 0,92 & goed \\
\hline wo gedrag en maatschappij & 0,9 & 3,5 & 2,8 & 1,00 & goed \\
\hline politicologie en sociologie & 1,1 & 3,4 & 2,4 & 0,97 & goed \\
\hline psychologie en maatschappelijk werk & 0,9 & 3,6 & 3,0 & 1,01 & redelijk \\
\hline wo onderwijs & 0,4 & 2,2 & 2,7 & 1,05 & redelijk \\
\hline onderwijs & 0,4 & 2,2 & 2,7 & 1,05 & redelijk \\
\hline wo medisch & 1,8 & 2,6 & 2,9 & 0,97 & goed \\
\hline (dier)geneeskunde en tandheelkunde & 1,4 & 3,2 & 2,5 & 0,91 & goed \\
\hline gezondheidszorg & 2,2 & 1,6 & 3,6 & 1,02 & redelijk \\
\hline
\end{tabular}

* Prognoses als gemiddeld jaarlijks percentage van de werkzame beroepsbevolking in 2016 
Tabel 5

Belangrijkste beroepen voor schoolverlaters met een bepaalde opleidingsachtergrond (opleidingstype) in Gelderland, gemiddelde van 2015$2016^{*}$

\begin{tabular}{|c|c|c|c|c|}
\hline Opleidingstypes en beroepsgroepen & \multicolumn{2}{|c|}{ Aantal werkenden } & \multicolumn{2}{|c|}{ Aandeel beroep in opleiding } \\
\hline basisonderwijs/vmbo & 220.000 & & 100 & \\
\hline Laders, lossers en vakkenvullers & & 16.500 & & 7,6 \\
\hline Schoonmakers & & 16.000 & & 7,4 \\
\hline Verkoopmedewerkers detailhandel & & 12.000 & & 5,5 \\
\hline Kelners en barpersoneel & & 7.000 & & 3,2 \\
\hline Administratief medewerkers & & 7.000 & & 3,2 \\
\hline Overig & & 161.500 & & 73,1 \\
\hline havo/vwo & 79.000 & & 100 & \\
\hline Kelners en barpersoneel & & 6.000 & & 7,7 \\
\hline Verkoopmedewerkers detailhandel & & 5.500 & & 7,1 \\
\hline Administratief medewerkers & & 4.500 & & 5,8 \\
\hline Laders, lossers en vakkenvullers & & 4.000 & & 5,2 \\
\hline Kassamedewerkers & & 2.500 & & 3,2 \\
\hline Overig & & 56.500 & & 71,0 \\
\hline mbo $2 / 3$ bouw en infra & 11.500 & & 100 & \\
\hline Timmerlieden & & 2.500 & & 21,4 \\
\hline Overig & & 9.000 & & 78,6 \\
\hline mbo $2 / 3$ gezondheidszorg & 28.500 & & 100 & \\
\hline Verzorgenden & & 14.000 & & 49,2 \\
\hline Sociaal werkers, groeps- en woonbegeleiders & & 2.500 & & 8,8 \\
\hline Verpleegkundigen (mbo) & & 1.500 & & 5,3 \\
\hline Gespecialiseerd verpleegkundigen & & 1.000 & & 3,5 \\
\hline Overig & & 9.500 & & 33,2 \\
\hline mbo 4 commercieel, financieel en administratief & 20.000 & & 100 & \\
\hline Boekhoudkundig medewerkers & & 3.000 & & 15,0 \\
\hline Administratief medewerkers & & 1.500 & & 7,5 \\
\hline Overig & & 15.500 & & 77,5 \\
\hline mbo 4 detailhandel & 14.500 & & 100 & \\
\hline Verkoopmedewerkers detailhandel & & 2.000 & & 14,0 \\
\hline Overig & & 12.500 & & 86,0 \\
\hline mbo 4 secretarieel & 15.500 & & 100 & \\
\hline Administratief medewerkers & & 1.500 & & 9,7 \\
\hline Boekhoudkundig medewerkers & & 1.500 & & 9,7 \\
\hline Directiesecretaresses & & 1.500 & & 9,7 \\
\hline Overig & & 11.000 & & 70,9 \\
\hline mbo 4 technische installatie & 10.500 & & 100 & \\
\hline Elektriciens en elektronicamonteurs & & 2.000 & & 18,8 \\
\hline Overig & & 8.500 & & 81,2 \\
\hline mbo 4 voedsel, natuur en milieu & 11.500 & & 100 & \\
\hline Veetelers & & 1.500 & & 12,9 \\
\hline Overig & & 10.000 & & 87,1 \\
\hline mbo 4 gezondheidszorg & 23.500 & & 100 & \\
\hline Verzorgenden & & 4.000 & & 17,0 \\
\hline Verpleegkundigen (mbo) & & 3.500 & & 14,9 \\
\hline
\end{tabular}




\begin{tabular}{|c|c|c|c|c|}
\hline Gespecialiseerd verpleegkundigen & & 2.500 & & 10,6 \\
\hline Medisch praktijkassistenten & & 2.500 & & 10,6 \\
\hline Sociaal werkers, groeps- en woonbegeleiders & & 2.000 & & 8,5 \\
\hline Overig & & 9.000 & & 38,4 \\
\hline mbo 4 maatschappelijke zorg & 14.000 & & 100 & \\
\hline Sociaal werkers, groeps- en woonbegeleiders & & 5.000 & & 36,1 \\
\hline Leidsters kinderopvang en onderwijsassistenten & & 1.500 & & 10,8 \\
\hline Overig & & 7.500 & & 53,1 \\
\hline hbo leraar basisonderwijs & 18.000 & & 100 & \\
\hline Leerkrachten basisonderwijs & & 10.500 & & 58,2 \\
\hline Overig & & 7.500 & & 41,8 \\
\hline hbo marketing en commerciële economie & 13.000 & & 100 & \\
\hline Adviseurs marketing, public relations en sales & & 2.000 & & 15,6 \\
\hline Overig & & 11.000 & & 84,4 \\
\hline hbo bedrijfskunde en hrm & 21.500 & & 100 & \\
\hline Specialisten personeels- en loopbaanontwikkeling & & 2.000 & & 9,3 \\
\hline Bedrijfskundigen en organisatieadviseurs & & 1.500 & & 6,9 \\
\hline Overig & & 18.000 & & 83,8 \\
\hline hbo verpleegkunde en medische diagnostiek & 18.000 & & 100 & \\
\hline Gespecialiseerd verpleegkundigen & & 6.500 & & 35,8 \\
\hline Medisch praktijkassistenten & & 2.500 & & 13,8 \\
\hline Overig & & 9.000 & & 50,4 \\
\hline hbo maatschappelijk werk & 16.500 & & 100 & \\
\hline Sociaal werkers, groeps- en woonbegeleiders & & 5.000 & & 30,1 \\
\hline Maatschappelijk werkers & & 3.500 & & 21,0 \\
\hline Overig & & 8.000 & & 48,9 \\
\hline wo bedrijfskunde en hrm & 15.500 & & 100 & \\
\hline Bedrijfskundigen en organisatieadviseurs & & 1.500 & & 9,6 \\
\hline Overig & & 14.000 & & 90,4 \\
\hline wo (dier)geneeskunde en tandheelkunde & 11.000 & & 100 & \\
\hline Artsen & & 8.000 & & 74,0 \\
\hline Overig & & 3.000 & & 26,0 \\
\hline
\end{tabular}

* Als gevolg van lage celvulling kan voor een deel van de opleidingstypes niet meer dan één beroepsgroep worden weergegeven. 
Van opleiding naar beroep

Om een beeld te krijgen van wat de Gelderse prognoses naar opleidingstype betekenen voor de verwachte knelpunten naar beroep, is het relevant om eerst nader in te gaan op de belangrijkste beroepsgroepen per opleidingstype. Dit is weergeven in Tabel 5. Om plaats te besparen zijn enkel de opleidingstypes opgenomen die meer dan Io.ooo werkenden hebben, en zijn maximaal de vijf grootste beroepsgroepen getoond.

Degenen die slechts uitsluitend het basisonderwijs of vmbo doorlopen hebben, zijn het vaakst werkzaam als laders, lossers en vakkenvullers $(7,6 \%)$ en schoonmakers $(7,4 \%)$, terwijl degenen met een diploma van het havo en vwo het vaakst werken als kelners en barpersoneel $(7,7 \%)$ en als verkoopmedewerkers detailhandel (7,I\%). Verder blijkt dat bijna de helft van de werkzame gediplomeerden van mbo $2 / 3$ gezondheidszorg uit verzorgenden bestaat, gevolgd door sociaal werkers, groeps- en woonbegeleiders $(8,8 \%)$ en verpleegkundigen mbo $(5,3 \%)$. Ook bij mbo 4 gezondheidszorg vormen verzorgenden de grootste beroepsgroep, maar is hun aandeel aanzienlijk kleiner dan bij mbo $2 / 3$ (17\%). Onder de werkenden met een opleiding mbo 4 secretarieel zijn de belangrijkste beroepsgroepen boekhoudkundig medewerkers, administratief medewerkers en directiesecretaresses. Opvallend is bovendien dat ze alle drie even vaak voorkomen (9,7\%).

Met betrekking tot de hogere opleidingstypes komt naar voren dat $58,2 \%$ van gediplomeerden van hbo leraar basisschool effectief als leerkracht basisschool werkzaam is. $\mathrm{Bij}$ de hogere zorg-opleidingen valt op dat binnen hbo verpleegkunde en medische diagnostiek de grootste beroepsgroepen gevormd worden door gespecialiseerd verpleegkundigen $(35,8 \%)$ en medisch praktijkassistenten $(\mathrm{I} 3,8 \%)$, en dat drie op de vier werkende gediplomeerden van wo (dier)geneeskunde en tandheelkunde werkzaam zijn als arts. De belangrijkste beroepsgroepen die horen bij hbo maatschappelijk werk zijn ten slotte sociaal werkers, groepswoonbegeleiders $(30,1 \%)$ en maatschappelijk werkers $(2 \mathrm{I} \%)$.

\section{Knelpunten naar beroepsgroep}

De arbeidsmarktprognoses naar opleidingstype maken het mogelijk om de Indicator voor de Toekomstige Knelpunten in de Personeelsvoorziening naar Beroepsgroep (ITKB) op te stellen. Deze indicator geeft aan in welke mate de gewenste personeelssamenstelling per beroepsgroep kan worden voldaan gegeven de verwachte vraag en het verwachte aanbod van de opleidingstypes die voor deze personeelssamenstelling vereist zijn. Een ITKB van exact I betekent dat er geen knelpunten worden voorzien bij het vervullen van de vraag vanuit de beroepsgroep in kwestie, terwijl een ITKB van o impliceert dat de vraag vanuit de beroepsgroep in zijn geheel niet kan worden vervuld.

Tabel 6 geeft een kwalitatieve typering voor de ITKB voor elk van de $I$ I2 onderscheiden beroepsgroepen. Hoe deze typeringen zijn vastgesteld, is uitgelegd in Tekstbox I. Steeds is ook aangegeven tot welke beroepsklasse de beroepsgroepen behoren. ${ }^{6}$ Deze beroepenindeling geeft echter niet aan dat er tijdens de prognoseperiode ook nieuwe beroepen kunnen ontstaan, of dat de inhoud van een beroep kan veranderen, als gevolg van bijvoorbeeld technologische vooruitgang, robotisering en digitalisering. De hieruit resulterende vraag naar hoger opgeleiden met nieuwe vaardigheden en in hogere functies ontstaat echter voor ongeveer $60 \%$ binnen bestaande beroepen, wat dit de belangrijkste bepalende factor voor het toekomstige beroepenlandschap maakt. Daarnaast kan een beroep zich ook opsplitsen wanneer het aantrekkelijk wordt om bepaalde taken te bundelen in een nieuwe, aparte, functie. ${ }^{?}$

Zoals blijkt uit de tabel, wordt voor bijna de helft van de beroepsgroepen tot 2022 geen of vrijwel geen knelpunten verwacht. Vaak gaat het om commerciële beroepen en om bedrijfseconomische en administratieve beroepen, wat deels kan verklaard worden door de verwachte impact van automatisering en digitalisering. Voorbeelden van beroepsgroepen waarvoor helemaal geen knelpunten worden verwacht zijn kassamedewerkers, boekhouders, boekhoudkundig medewerkers, secretaresses, callcentermedewerkers, winkeliers en teamleiders detailhandel. Verder worden er ookgeen knelpunten voorzien voor de vacature-invulling bij de agrarische beroepen. Dit weerspiegelt de verwachte werkgelegenheidskrimp van de Gelderse landbouw, bosbouw en visserij. Voorbeelden van beroepsgroepen die hieronder vallen zijn land- en bosbouwers, veetelers en hulpkrachten landbouw.

Vrijwel geen knelpunten worden voorzien bij het rekruteren van overheidsambtenaren, administratief medewerkers en politie-inspecteurs. Hetzelfde geldt voor sommige beroepsgroepen in zorg en welzijn, zoals verzorgenden, medisch vakspecialisten en maatschappelijk

6 In het bijgeleverde Excel-bestand zijn ook de absolute ITKB-scores opgenomen, alsmede de ITKB-typeringen naar beroepsgroep voor Nederland als geheel. De Nederlandse ITKB's en ITKB-typeringen zijn echter niet in deze tabel opgenomen omdat de typeringen moeilijk te vergelijken zijn met deze van Gelderland (zie Tekstbox I voor meer uitleg over de ITKB-typering).

7 Zie voor een uiteenzetting over de verandering in de vraag naar vaardigheden D. Fouarge, Verandering in werk en vaardigheden, oratie 29 juni 20I7, Universiteit Maastricht. Voor meer informatie over het effect van robotisering en digitalisering op de ITKB, zie de tekstbox in ROA (2017), De arbeidsmarkt naar opleiding en beroep tot 2022, Maastricht: ROA-R-20I7/Io. 
werkers. Grote knelpunten worden in deze beroepsklasse echter voorzien voor fysiotherapeuten, psychologen, sociologen, laboranten en medisch praktijkassistenten. Voor artsen en verpleegkundigen (mbo) worden zelfs zeer grote knelpunten verwacht. Naast verpleegkundigen op mbo-niveau zijn het dus hoofdzakelijk zorgberoepen die hbo- en wo-gediplomeerden vereisen waarvoor de komende zes jaar grote knelpunten verwacht worden. Dit komt door een stijgende vraag naar zorg door de toenemende vergrijzing, en door nieuwe investeringen in de sector.

Binnen de pedagogische beroepen valt op dat er voor docenten van beroepsgerichte en algemene vakken in het secundair onderwijs vrijwel geen knelpunten worden verwacht. In tegenstelling tot Nederland, wordt voor Gelderland geen groei verwacht in de vraag naar werkenden met een achtergrond hbo leraar beroepsgerichte vakken. De vraag naar werkenden met deze achtergrond bestaat alleen uit vervangingsvraag voor mensen die met pensioen gaan of anderszins uitstromen. Voor de vraag naar werkenden met een opleiding als hbo leraar algemene vakken geldt over het algemeen dat er voldoende studenten in de lerarenopleidingen zijn om aan de vraag te voldoen, maar dat er wel belangrijke verschillen tussen vakken kunnen voorkomen. Voor de vraag naar hoogleraren en docenten hoger onderwijs worden daarentegen grote knelpunten verwacht. Voor leerkrachten basisonderwijs zullen naar verwachting zelfs zeer grote knelpunten te zien zijn.

In tegenstelling tot de commerciële, bedrijfseconomische en administratieve beroepen worden binnen de technische beroepen en de ICT-beroepen relatief veel knelpunten verwacht. Grote knelpunten worden bijvoorbeeld voorzien voor auto- en machinemonteurs, loodgieters, pijpfitters en databank- en netwerkspecialisten. Bij het rekruteren van (elektrotechnisch) ingenieurs, elektriciens, elektronicamonteurs, architecten, technici bouwkunde en natuur en software- en applicatieontwikkelaars worden zelfs zeergroteknelpuntenverwacht. Enigeknelpunten worden ten slotte voorzien voor timmerlieden, assemblagemedewerkers, procesoperators en productcontroleurs.
Voor de meeste dienstverlenende beroepen worden tot 2022 (vrijwel) geen knelpunten verwacht. Hierbij gaat het bijvoorbeeld om koks, kelners, barpersoneel, schoonmakers, kappers en schoonheidsspecialisten. Specifiek voor koks zou dit verklaard kunnen worden doordat bij vacatures voor koks vaak personen worden aangetrokken zonder een koksdiploma, die vervolgens worden ingehuurd tegen relatief slechte arbeidsvoorwaarden. Wanneer veel werkgevers de loonkosten voor gediplomeerde koks niet willen dragen, leidt dit tot minder knelpunten voor gediplomeerde koks. Voor keukenhulpen en verleners van overige persoonlijke diensten worden daarentegen respectievelijk enige en grote knelpunten voorzien.

Binnen de creatieve en taalkundige beroepen worden vrijwel geen knelpunten verwacht voor bibliothecarissen, conservatoren en journalisten, terwijl er grote knelpunten worden voorzien voor zowel beeldend en uitvoerend kunstenaars als grafisch vormgevers en productontwerpers. De redenen voor de grote knelpunten in deze laatste beroepen kunnen ermee te maken hebben dat de kunstopleidingen op hbo-niveau zich hebben ontwikkeld tot vrij brede toegepaste opleidingen, die vaak gericht zijn op grafische vormgeving en zakelijke dienstverlening. Bovendien is de instroom van studenten in de autonome beeldende kunsten wat teruggedrongen. Mogelijk heeft dit de arbeidsmarktperspectieven van deze opleidingen flink verbeterd.

Ook de management beroepen laten een gemengd beeld zien. Terwijl vrijwel geen knelpunten worden verwacht bij het rekruteren van managers in de horeca, detail- en groothandel, worden er grote knelpunten voorzien bij het werven van bijvoorbeeld managers in de ICT, het onderwijs en de zorg. Binnen de transport en logistieke beroepen worden geen knelpunten verwacht voor buschauffeurs en trambestuurders, maar wel voor vuilnisophalers en dagbladenbezorgers. Verder valt op dat er weinig knelpunten worden voorzien chauffeurs van vrachtwagens, auto's, taxi's en bestelwagens. Dit zou kunnen verklaard worden doordat er weinig of geen vraag is naar Nederlandse chauffeurs, maar wel naar buitenlandse chauffeurs, wat niet in de Nederlandse uitbreidingsvraag is meegenomen. 
Tabel 6

Verwachte knelpunten naar beroepsgroep (2017-2022), ITKB-typeringen gaan van geen, vrijwel geen, enige, grote tot zeer grote knelpunten

\begin{tabular}{|c|c|c|}
\hline Beroepsklasse & Beroepsgroep & ITKB-typering \\
\hline \multirow[t]{8}{*}{ Pedagogische beroepen } & Docenten hoger onderwijs en hoogleraren & groot \\
\hline & Docenten beroepsgerichte vakken secundair onderwijs & vrijwel geen \\
\hline & Docenten algemene vakken secundair onderwijs & vrijwel geen \\
\hline & Leerkrachten basisonderwijs & zeer groot \\
\hline & Onderwijskundigen en overige docenten & groot \\
\hline & Sportinstructeurs & geen \\
\hline & Leidsters kinderopvang en onderwijsassistenten & vrijwel geen \\
\hline & Totaal & enige \\
\hline \multirow[t]{8}{*}{ Creatieve en taalkundige beroepen } & Bibliothecarissen en conservatoren & vrijwel geen \\
\hline & Auteurs en taalkundigen & enige \\
\hline & Journalisten & vrijwel geen \\
\hline & Beeldend kunstenaars & groot \\
\hline & Uitvoerend kunstenaars & groot \\
\hline & Grafisch vormgevers en productontwerpers & groot \\
\hline & Fotografen en interieurontwerpers & enige \\
\hline & Totaal & groot \\
\hline \multirow[t]{7}{*}{ Commerciële beroepen } & Adviseurs marketing, public relations en sales & enige \\
\hline & Vertegenwoordigers en inkopers & geen \\
\hline & Winkeliers en teamleiders detailhandel & geen \\
\hline & Verkoopmedewerkers detailhandel & vrijwel geen \\
\hline & Kassamedewerkers & geen \\
\hline & Callcentermedewerkers outbound en overige verkopers & geen \\
\hline & Totaal & geen \\
\hline \multirow[t]{14}{*}{ Bedrijfseconomische en administratieve beroepen } & Accountants & enige \\
\hline & Financieel specialisten en economen & enige \\
\hline & Bedrijfskundigen en organisatieadviseurs & groot \\
\hline & Beleidsadviseurs & enige \\
\hline & Specialisten personeels- en loopbaanontwikkeling & vrijwel geen \\
\hline & Boekhouders & geen \\
\hline & Zakelijke dienstverleners & vrijwel geen \\
\hline & Directiesecretaresses & geen \\
\hline & Administratief medewerkers & vrijwel geen \\
\hline & Secretaresses & geen \\
\hline & Receptionisten en telefonisten & enige \\
\hline & Boekhoudkundig medewerkers & geen \\
\hline & Transportplanners en logistiek medewerkers & groot \\
\hline & Totaal & vrijwel geen \\
\hline \multirow[t]{8}{*}{ Managers } & Algemeen directeuren & groot \\
\hline & Managers zakelijke en administratieve dienstverlening & enige \\
\hline & Managers verkoop en marketing & enige \\
\hline & Managers productie & groot \\
\hline & Managers logistiek & vrijwel geen \\
\hline & Managers ICT & groot \\
\hline & Managers zorginstellingen & groot \\
\hline & Managers onderwijs & groot \\
\hline
\end{tabular}




\begin{tabular}{|c|c|c|}
\hline & Managers gespecialiseerde dienstverlening & groot \\
\hline & Managers horeca & vrijwel geen \\
\hline & Managers detail- en groothandel & vrijwel geen \\
\hline & Managers commerciële en persoonlijke dienstverlening & groot \\
\hline & Totaal & enige \\
\hline \multirow[t]{8}{*}{ Openbaar bestuur, veiligheid en juridische beroepen } & Overheidsbestuurders & groot \\
\hline & Overheidsambtenaren & vrijwel geen \\
\hline & Juristen & zeer groot \\
\hline & Politie-inspecteurs & vrijwel geen \\
\hline & Politie en brandweer & enige \\
\hline & Beveiligingspersoneel & enige \\
\hline & Militaire beroepen & geen \\
\hline & Totaal & vrijwel geen \\
\hline \multirow[t]{26}{*}{ Technische beroepen } & Biologen en natuurwetenschappers & groot \\
\hline & Ingenieurs (geen elektrotechniek) & zeer groot \\
\hline & Elektrotechnisch ingenieurs & zeer groot \\
\hline & Architecten & zeer groot \\
\hline & Technici bouwkunde en natuur & zeer groot \\
\hline & Productieleiders industrie en bouw & groot \\
\hline & Procesoperators & enige \\
\hline & Bouwarbeiders ruwbouw & vrijwel geen \\
\hline & Timmerlieden & enige \\
\hline & Bouwarbeiders afbouw & enige \\
\hline & Loodgieters en pijpfitters & groot \\
\hline & Schilders en metaalspuiters & enige \\
\hline & Metaalbewerkers en constructiewerkers & vrijwel geen \\
\hline & Lassers en plaatwerkers & vrijwel geen \\
\hline & Automonteurs & groot \\
\hline & Machinemonteurs & groot \\
\hline & Slagers & geen \\
\hline & Bakkers & groot \\
\hline & Productcontroleurs & enige \\
\hline & Meubelmakers, kleermakers en stoffeerders & geen \\
\hline & Medewerkers drukkerij en kunstnijverheid & vrijwel geen \\
\hline & Elektriciens en elektronicamonteurs & zeer groot \\
\hline & Productiemachinebedieners & vrijwel geen \\
\hline & Assemblagemedewerkers & enige \\
\hline & Hulpkrachten bouw en industrie & enige \\
\hline & Totaal & groot \\
\hline \multirow[t]{5}{*}{ ICT beroepen } & Software- en applicatieontwikkelaars & zeer groot \\
\hline & Databank- en netwerkspecialisten & groot \\
\hline & Gebruikersondersteuning ICT & vrijwel geen \\
\hline & Radio- en televisietechnici & groot \\
\hline & Totaal & groot \\
\hline \multirow[t]{4}{*}{ Agrarische beroepen } & Land-en bosbouwers & geen \\
\hline & Hoveniers, tuinders en kwekers & geen \\
\hline & Veetelers & geen \\
\hline & Hulpkrachten landbouw & geen \\
\hline
\end{tabular}




\begin{tabular}{|c|c|c|}
\hline & Totaal & geen \\
\hline \multirow[t]{13}{*}{ Zorg en welzijn beroepen } & Artsen & zeer groot \\
\hline & Gespecialiseerd verpleegkundigen & enige \\
\hline & Fysiotherapeuten & groot \\
\hline & Maatschappelijk werkers & vrijwel geen \\
\hline & Psychologen en sociologen & groot \\
\hline & Laboranten & groot \\
\hline & Apothekersassistenten & vrijwel geen \\
\hline & Verpleegkundigen (mbo) & zeer groot \\
\hline & Medisch praktijkassistenten & groot \\
\hline & Medisch vakspecialisten & vrijwel geen \\
\hline & Sociaal werkers, groeps- en woonbegeleiders & geen \\
\hline & Verzorgenden & vrijwel geen \\
\hline & Totaal & enige \\
\hline \multirow[t]{9}{*}{ Dienstverlenende beroepen } & Reisbegeleiders & geen \\
\hline & Koks & geen \\
\hline & Kelners en barpersoneel & vrijwel geen \\
\hline & Kappers en schoonheidsspecialisten & vrijwel geen \\
\hline & Conciërges en teamleiders schoonmaak & geen \\
\hline & Verleners van overige persoonlijke diensten & groot \\
\hline & Schoonmakers & vrijwel geen \\
\hline & Keukenhulpen & enige \\
\hline & Totaal & geen \\
\hline \multirow[t]{8}{*}{ Transport en logistiek beroepen } & Dekofficieren en piloten & groot \\
\hline & Chauffeurs auto's, taxi's en bestelwagens & enige \\
\hline & Buschauffeurs en trambestuurders & geen \\
\hline & Vrachtwagenchauffeurs & vrijwel geen \\
\hline & Bedieners mobiele machines & vrijwel geen \\
\hline & Laders, lossers en vakkenvullers & vrijwel geen \\
\hline & Vuilnisophalers en dagbladenbezorgers & groot \\
\hline & Totaal & vrijwel geen \\
\hline
\end{tabular}




\section{Colofon}

( ) Researchcentrum voor Onderwijs en Arbeidsmarkt Niets uit deze uitgave mag op enige manier worden verveelvoudigd zonder voorafgaande schriftelijke toestemming van de directeur van het ROA.

Researchcentrum voor Onderwijs en Arbeidsmarkt

Maastricht University

School of Business and Economics

secretary-roa-sbe@maastrichtuniversity.nl

www.roa.n

\section{Vormgeving}

ROA secretariaat, Maastricht

juli 2018 